\title{
Consumer Preference Analysis between Local and Imported Rice Consumption in Adamawa State, Nigeria
}

\author{
Hamid, M. Y.*; Gabul, P.; Gabdo, B.H
}

Department of Agricultural Economics and Extension, Adamawa State University, P.M.B 25, Adamawa State, University Mubi, Nigeria *Corresponding Author

Received: 01 Nov 2020; Received in revised form: 22 Dec 2020; Accepted: 03 Jan 2021; Available online: 12 Jan 2021 (C)2021 The Author(s). Published by The Shillonga Publication. This is an open access article under the CC BY license (https://creativecommons.org/licenses/by/4.0/).

\begin{abstract}
The study was conducted in Adamawa state Nigeria. The objective was to analyze consumers' preference between local and imported rice in the area. A sample of 128 House Holds Heads $\left(\mathrm{HHH}_{S}\right)$, were drawn using multi-stages, purposive and simple random sampling techniques. Primary data was generated using structured questionnaire administered to 128 HHHs. However, only 120 were retrieved and subjected to both descriptive and inferential statistics. The descriptive statistics includes frequency count, percentages and means while chi-square analysis was used to test the hypothesis of the study which was stated in a null form, that local rice is better than the imported rice based on certain attributes such as price, swelling capacity, taste, cleanliness, cooking duration, color, odor, grain shape and in the preparation of different recipe. The results revealed that, majority (66.66\%), of the consumers prefer local rice based on it lower price and taste respectively while majority (83.34\%), (75, 00\%) and (66.66\%) agreed that imported rice is better in terms of cleanliness, pleasant odor and grain shape. Similarly, rice consumers concur (50\%) and (50\%) on the cooking duration attributes of both local and imported rice respectively in the area. The study therefore, concluded that, imported rice is better than the local rice based on the percentages and chi-square result which rejected, the null hypothesis, and accepted the alternate ( $x^{2} c a l$ is greater than $x^{2}$ tab at probability level (alpha) $p=(0.05)$ and $(r-1)(c-1)$ degree of freedom. It is recommended that local rice should be improved in respect to it cleanliness, odor and grain shape which are the attributes by which foreign rice is considered better from this study for it to be competitive at national and international market scenes. This could be achieved through improvement in research and adoption of improved production and processing technologies.
\end{abstract}

Keywords-Consumer, Preference, Imported, Local, Rice.

\section{INTRODUCTION}

Rice (Oryza Sativa, and Oryza glaberrima,) is an important food crop that is consumed by more than 50 percent of the world population which is put at about 4.8 billion people resident in 176 countries with an estimated 2.89 billion people in Asia, 150.3 million people in America and over 40 million people in Africa as reported by International Rice Research Institute (IRRI, 2004). Ojehomon et al. (2009) reported Nigeria doubles as the largest rice producing and consuming nation in West African sub-region for the past ten years. The planting of rice covers about 146 million hectares of land annually representing about 11 percent of the world cultivated land (Kassali et al., 2010). It is the fastest growing staple food item in most African countries, providing the bulk of dietary energy to the growing population. In most developing countries in Africa, rice accounts for $715 \mathrm{kcal} / \mathrm{caput} / \mathrm{day}, 27$ percent of nutritional supply of energy, 20 percent of nutritional protein and 3 percent of nutritional fat (Kassali et al., 2010).

Rice is an important annual crop in Nigeria been a major staple, which can provide the nation's population with the nationally required food security minimum of 2,400 calories per person per day as reported Food and Agriculture Organization (FAO, 2014). The average Nigerian consumes 
$24.8 \mathrm{~kg}$ of rice per year, representing 9 per cent of annual calorie intake (IRRI, 2011). Due to its increasing contribution to the per capita calorie consumption of Nigerians, the demand for rice has been increasing at a much faster rate than domestic production and more than in any other African countries since mid-1970s (FAO, 2014). For instance, during the 1960s, Nigeria had the lowest per capita annual consumption of rice in the West African sub-region with an annual average of $3 \mathrm{~kg}$. Since then, Nigeria's per capital consumption levels have grown significantly at 7.3 per cent per annum. Consequently, per capital consumption during the 1980s increased to an annual average of $18 \mathrm{~kg}$ and reached $22 \mathrm{~kg}$ between $1995-2000$ and $38 \mathrm{~kg}$ between 2010 and 2016 (FAO, 2017).

As a response to the prevailing rice supply deficit situation in Nigeria, successive Nigerian governments intervened in the rice sector by increasing tariffs on imported rice so that local production could be encouraged. This was expected to widen the home market for the nation's local rice. The Government also established the Federal Rice Research Station (FRRS) at Badeggi in 1970 and the National Cereal Research Institute (NCRI) in 1974. Also established were the National Seed Service (NSS) with the assistance of the Food and Agriculture Organization in 1975, and Operation Feed the Nation (OFN) in 1976. Other government program were the River Basin Development Authority (RBDA), Agricultural Development Projects (ADPs), the National Grain Production Programs (NGPP), the Structural Adjustment Program (SAP), and the Presidential Initiative on Increased Rice Production, Processing and Export. The last mentioned program, was aimed at addressing the ever widening demand supply gap for rice and stimulating surplus rice harvest for export by the year 2007. The implementation of this initiative started in 2004 under which rice boxes containing $10 \mathrm{~kg}$ of rice seeds and agrochemicals for 0.25 hectares were sold to farmers in each state at N3, 500.00 per box (Bamidele et al., 2017)

The idea was to encourage farmers in each participating state to cultivate rice on at least 250 hectares of land. This initiative has thus, encouraged farmers to go into the production of rice. The emergence of the VEETEE rice company was another way to boost local rice production in Nigeria. The company has initiated a rice out-growers scheme with farmers to boost domestic output. The company has the facilities for destining and polishing rice in addition to basic milling which gave high quality local rice (FAO, 2004). The fact however remains despite various restrictions including a recent total ban on the importation of the commodity, foreign rice is still found in the Nigerian markets.

Consequently, it becomes imperative to conduct a study to ascertain the reasons for the continued presence and preference for imported rice in the Nigerian markets today sixteen years after the implementation of Presidential Initiatives on Increased Rice Production, Processing and Export.

Consumer Preference between local and imported rice is usually anchored on certain attributes such as pricing, taste, swelling capacity, cooking duration, cleanliness, odor/aroma, color, grain shape and suitability for different recipe among others which provides the greatest level of satisfaction as described by the consumers. However, there is dearth of information on regarding these attributes and how they influence consumer preference in Adamawa State, Nigeria even though there were few studies elsewhere but consumers are very much constrained in their choice of rice due to inadequate information.

Questions this study seeks to provide answer therefore were: what are the attributes consumers consider when making a choice between local and imported rice in the area? What is the pattern of rice consumption? Are the pattern of consumption and the attributes of rice governing preferences similar to other areas previously studied?

\section{Objectives}

The major objective of the study was to analyze the consumer's preference between local and imported rice in the area. Specific objectives were to; identify attributes which consumers based their decision between consuming imported or local rice in the area, describe rice consumption pattern in the study area and based on the results compare the findings with other previous studies elsewhere

\section{Hypothesis}

The hypothesis for the study stated in a null form (Ho) was that local rice is preferred than the imported rice based on certain attributes in the study area.

\section{MATERIALS AND METHOD}

\section{The Study Area}

Adamawa State located in the North Eastern part of Nigeria between latitude $7^{\circ}$ and $11^{\circ} \mathrm{N}$ and Longitude $11^{\circ}$ and $14^{\circ} \mathrm{E}$. It shares boundary with Taraba State in the south and west, Gombe State in its North-west and Borno State to the North. The State has an international boundary with the Cameroon 
Republic along its eastern side. It has a land area of about $38,741 \mathrm{~km}^{2}$ (Adebayo, 1999). The State is divided into 21 Local Government areas. Adamawa State has a tropical wet and dry climate. Dry season lasts for a minimum of five months (November-March) while the wet season spans April to October (Adebayo, 1997).

The State is naturally divided into two ecological zones; the guinea and Sudan savannah zones. In general, the distribution of vegetation reflects the combined control of rainfall, topography and to a lesser extent, that of soils. Agriculture is the mainstay of about $80 \%$ of the inhabitants of the State. The ecological condition of the State permits cultivation of root crops, cereals and rearing of livestock in large numbers.

Maximum temperature is as high as $40^{\circ} \mathrm{C}$ especially between March and April with a minimum temperature as low as $18^{\circ} \mathrm{C}$ between December and January. This temperature range is good for rice enterprise especially during grain formation and during drying after parboiling among small scale rice millers. The relative humidity between January and March ranges from 20-30\% and reached a peak of $80 \%$ in August and September (Adebayo, 1997). The mean annual rainfall is about $1000 \mathrm{~mm}$, which allow the cultivation of rice and other crop such as ground nut, guinea corn, cowpea and vegetable of different kinds (Adebayo, 1997).

\section{Sampling Techniques}

Multi stage, purposive and simple random sampling techniques were used for the study. The first stage involved consideration of the 4 Agricultural zones demarcated by Adamawa State Agricultural Development Project (ADP) Namely, Zone I, II. I11 and $1 \mathrm{~V}$ respectively. The second stage involved purposive selection of 21 Local Government Areas (LGAs) from each zone making a total of 8 LGAs. The third stage involved purposive selection of one Urban/ Peri -Urban settlement and one rural settlement from each LGA; this gave a total of 16 settlements in the state.

The fourth stage involved collection/generation of lists of households in each of the ward (settlements) from the districts head office which serve as the sampling frame. The last stage involved simple random selection of 8 households' heads from the 16 wards (settlements) from the list which served as the sample size which gave a total of 128 respondents which served as the sample size for the study (see table 1). It should be noted, that the population of the study supposed to be all the household heads in the study area, however this will be too large and cumbersome to handle.

Table 1: Showing sampling distribution of respondents according to zones, local government areas and wards

\begin{tabular}{|c|c|c|c|c|}
\hline \multirow{2}{*}{$\begin{array}{l}\text { Zones } \\
\text { Zone I }\end{array}$} & \multirow{2}{*}{$\begin{array}{l}\text { Local Government Areas } \\
\text { Mubi - North }\end{array}$} & \multicolumn{2}{|c|}{ Wards Households } & \multirow{2}{*}{$\begin{array}{c}\text { Sample Households Heads } \\
8\end{array}$} \\
\hline & & Yelwa & 419 & \\
\hline & & Mayo - bani & 97 & 8 \\
\hline & Mubi - South & Nassarawo & 274 & 8 \\
\hline & & Mujjara & 142 & 8 \\
\hline \multirow[t]{4}{*}{ Zone II } & Gombi & Gombi-North & 149 & 8 \\
\hline & & Garkida & 55 & 8 \\
\hline & Song & Song Gari & 240 & 8 \\
\hline & & Zumo & 106 & 8 \\
\hline \multirow[t]{4}{*}{ Zone III } & Yola- south & Adarawo & 188 & 8 \\
\hline & & Ngurore & 336 & 8 \\
\hline & Fufore & Fufore & 562 & 8 \\
\hline & & Ribadu & 119 & 8 \\
\hline \multirow[t]{5}{*}{ Zone IV } & Numan & Numan & 319 & 8 \\
\hline & & Imburu & 68 & 8 \\
\hline & Lamurde & Lafiya & 119 & 8 \\
\hline & & Gyawana & 180 & 8 \\
\hline & Total & & & 128 \\
\hline
\end{tabular}

Source: Field survey, 2019. 
Data Collection

Data for the study was generated from primary source. Primary data was collected from rice consumers identified at the households levels through the use of structured questionnaire administered to Households Heads. Information captured were on attributes which consumers consider when consuming rice and rice consumption patterns.

\section{Data Analyses}

Data collected was subjected to descriptive and inferential analyses. The descriptive statistics includes frequency counts, percentages and means. The inferential statistics is the Chi - square.

\section{Descriptive statistics}

Frequency count, this is achieved by taking count of any observation. Percentage is obtained by taking the share of each observation from the total distribution and multiplying by 100 . The result is presented in table 2 .

Table 2: Preference distribution between local and imported rice based on some selected attributes

\begin{tabular}{lccccccc}
\multicolumn{1}{c}{ Attributes } & \multicolumn{2}{c}{ Local } & & Imported & \multicolumn{2}{c}{ Total } \\
& Frequency & $\%$ & Frequency & $\%$ & Frequency & $\%$ \\
\hline Character of price desired & 80 & 66.66 & 40 & 33.34 & 120 & 100 \\
Character of swelling capacity desired & 70 & 58.33 & 50 & 41.67 & 120 & 100 \\
Character of taste desired & 80 & 66.66 & 40 & 33.34 & 120 & 100 \\
Character of cleanliness & 20 & 16.66 & 100 & 33.34 & 120 & 100 \\
Character of cooking duration & & & & & & & 100 \\
desired & 60 & 50.00 & 60 & 50.00 & 120 & 100 \\
Character of color desired & 20 & 16.66 & 100 & 33.34 & 120 & 100 \\
Character of odour desired & 30 & 25.00 & 90 & 75.00 & 120 & 100 \\
Character of grain shape desired & 40 & 33.34 & 80 & 66.67 & 120 & 100 \\
Character of suitability of recipe & 50 & 41.67 & 70 & 58.33 & 120 & 100 \\
\hline
\end{tabular}

\section{Source: Survey data, 2019}

\section{DISCUSSION}

Table 2 presents analysis of local and imported rice based on price. It revealed that majority $(66.66 \%)$ of the rice consumers prefer local rice based on price. This shows that local rice is preferred to imported rice due to its relative cheapness to imported rice in the area. The decision to buy local rice could be due to it cheaper priced relative to imported rice which is usually expensive and not minding the quality. Mhalaga (2010) in his study conducted on economic analysis of consumer based attributes for rice in Benin republic, reported that, both domestic and imported rice have positive and negative implicit prices implying that the quality of a product attract price. Higher quality, attract good price and vice versa. The result also reported that, there is a statistically significant difference between the mean price for imported and domestic rice $(t=9.7937$ and $\mathrm{p}=$
0.0000). Ariff and Ayob (2017) also in a study conducted in Kelantan, Malasysia, on preference of consumer toward imported and local rice, reported that, the economic value of a commodity is revealed by the consumers' willingness to pay for the commodity.

The table present results on consumer preference based on swelling capacity of rice. It revealed that majority (58.33\%) of the consumers prefer local rice than the imported due it high swelling capacity relative to import. This implied that consumers based their decision to consume local rice based on it higher swelling capacity.

The table present result on rice consumer preference based on taste attribute. It found that majority $(66.66 \%)$ of rice consumers in the area prefer local rice to imported rice based on it taste implying that, consumers based their decision to buy local rice to imported rice due to it taste. Opeyemi et. 
al., (2015) in their study on analysis of consumers preference in patronizing locally produced and imported rice in Niger state Nigeria, reported that, taste of rice ranked $4^{\text {th }}$ among the determinants of rice consumption in the area.

The table present result on consumers preference based on cleanliness of rice. It revealed that majority $(83.33 \%)$ of rice consumers in the area prefer imported rice to local rice because of cleanliness implying that consumers based their decision to buy imported rice relative to local rice in the area due to it cleanliness attribute.

The table present result on consumers preference based on cooking duration. It found that $50 \%$ and $50 \%$ of consumers respectively prefer local and imported rice in terms of cooking duration attribute in the area. This implies that, they don't see any difference in terms of cooking duration. Therefore, they based their decisions considering other attributes rather than cooking time.

The table present result on consumers preference based on color appeal attributes. It revealed that majority (83.33\%) of the rice consumers in the area prefer imported rice to local rice in terms of color attributes. This implies that consumer based their decision to buy imported rice against the local rice based on it color which is brighter than the local rice.

The table present result on consumers preference based on perceived odor between local and imported rice. It found that majority $(75.00 \%)$ of the consumer prefer imported rice to local rice based on it perceived odor implying that rice consumers in the area based their decision to consume rice due to its presence or absence of unpleasant odor. Therefore, the imported rice is prefer to local rice due to it pleasant aroma.

The table present result on consumers preference based on grain shape. It found that majority (66.67\%) of the consumers prefer imported to local rice in terms of it grain shape implying that imported rice has uniform size than the local rice. This shows imported rice consumers based their decision to purchase imported rice based on it grain shape.

The table present result on suitability of recipe/preparation. It found that majority $(58.37 \%)$ prefer imported to local rice in terms of preparation of different types of recipe. This implies that rice consumers in the area based their rice purchase decision of imported rice due to it suitability for preparing default recipe.

Mhalaga (2010) in his study conducted on economic analysis of consumer based attributes for rice in Benin republic, reported that, consumers are becoming more aware of the quality of attributes of different commodities found in the market and are choosing products that closely match their taste and preferences. He further reported that consumers pay a premium for grain size, aroma, color, wholeness and cleanliness of grains and cooking conveniences attributes across different region studied.

\section{Chi - square analysis}

Chi - square analysis was used to test the hypothesis for the study which was stated in a null form that local rice is preferred than the imported rice based on certain attributes in the study area

The formula for the Chi - square is presented below:

$x^{2}=\sum{\underline{(\mathrm{o}-\mathrm{e})^{2}}}^{2}$

$\mathrm{e}$

Where:

$x^{2}=$ chi-square

$\mathrm{o}=$ observe response

$\mathrm{e}=$ expected response

Table 3: Chi- square distribution of attributes influencing Local and imported rice consumption

$\begin{array}{llll}\text { Attributes } & (\mathbf{o}-\mathbf{e}) \quad(\mathbf{o}-\mathbf{e})^{2} & \underline{(\mathrm{o}-\mathrm{e})^{2}}\end{array}$

$\mathrm{e}$

Character of price desired

Character of swelling capacity desired

Character of taste

desired

Character of cleanliness

Character of cooking duration desired
400

100

400

1600

225
6.66

1.66

6.66

26.66

3.75 
Character of color desired

Character of odour desired

Character of grain shape desired

Character of suitability of recipe

$\sum{\underline{(\mathrm{o}-\mathrm{e})^{2}}}^{2}$

e

\section{Source; Survey data, 2019}

\section{Hypothesis Testing}

The hypothesis test was conducted at probability level $($ alpha $)=0.05$. Degree of freedom DF $(r-1)(c-1)$

$\mathrm{n}=9, \mathrm{DF}=8$

$x^{2}$ calculated $=95.37$

$x^{2}$ tabulated $=15.51$

\section{Decision Rule}

The calculated Chi-square $\left(x^{2}\right)$ is greater than the tabulated, so we reject the null hypothesis and accept the alternate. We therefore conclude that imported rice is better than the local rice based on certain attributes in the study area (there is significant difference statistically at 0.05 level of significant and $\mathrm{df}=(\mathrm{r}-1)(\mathrm{c}-1)$.

\section{CONCLUSION}

The study therefore, concluded that, rice consumers prefer imported rice against the local rice basically because of it cleanliness, pleasant appeal and grain shape.

\section{RECOMMENDATION}

It is recommended that local rice should be improved in respect to it cleanliness, odor and grain shape for it to be competitive in the national and international market scenes.

This could be achieved through improvement in research and adoption of improved production and processing technologies.

\section{REFERENCES}

[1] Adebayo, A. A. and Tukur, A. L. (1999). Climate I: Sunshine, Temperature, Evaporation and Relative humidity in Adamawa State in Maps. Paraclette Publishers, Yola. pp 20-22

[2] Adebayo, A. A. (1997). The Agro climatology of rice production in Adamawa State Nigeria unpublished PhD.

$\begin{array}{rr}1600 & 26.66 \\ 900 & 15.00 \\ 400 & 6.66 \\ 100 & 1.66\end{array}$

\section{37}

Thesis Department of Geography Federal University of Technology Yola.

[3] Bamba, I., Diagne, A., Manful, J., and Ajayi, A. (2010). Historic Opportunities for Rice Growers in Nigeria. Grain de sel. No. 51, July, - September, 2010

[4] Bamidele, D. O. and Ester, O. A. (2010 (2017). Analysis of the Relationships of Factors Affecting Rice Consumption in a Targeted Region in Ekiti - State, Nigeria. Journal of Applied Quantitative Methods 4 (2): 145-153.

[5] Food and Agriculture Organization (FAO) (2004). Rome, Italy World Rice. Research Conference 2004 Tsukuba, 5-7.

[6] Food and Agriculture Organization (FAO) (2006)."International Rice Newsletter." Food and Agriculture Organization vol. 55: Rome, Italy Accessed August to November 2009.

[7] Food and Agriculture Organization (FAO) (2014). "Food insecurity in the world." Food and Agriculture Organization Statistics Database accessed July to December 2015.

[8] Food and Agriculture Organization (FAO) (2017). Nigeria at a glance. www. fao. Org/nigeria/fao-in-nigeria/nigeria- ata-glance/en/. Hall.

[9] Gyimah-Brempong, Kwabena and Oluyemisi Kuku. (2014). "Evolution of Consumption and Demand Patterns" Chapter 2 in Gyimah-Brempong, Kwabena, Michael Johnson and Hiroyuki Takeshima (eds.) Transforming the Nigerian Rice Economy, University of Pennsylvania Press (forthcoming).

[10] International Rice Research Institute, (IRRI) (2004). World Rice Statistics. International Rice Research Institute, Manilla, Philippines.

[11] International Rice Research Institute, (IRRI) (2011). "Rice Policy - World rice statistics- trends in the rice economy." International Rice Research Institute database http://ricelib.irri.cgiar.org.

[12] Kassali, R., Kareem, R.O., Oluwasola, O. and Ohaegbulam, O.M. (2010) Analysis of Demand for Rice in Ile Ife, Osun State, Nigeria. Journal of Sustainable Development in Africa, Vol 12(2).

[13] Mhalanga, S. (2010). Economic Analysis of Consumer based attributes for rice in Benin. A thesis submitted to McGill University in partial fulfillment of the requirements of the degree of Master of Science

[14] Ojehomon, V.E.T., Adebayo, S.B., Ogundele, O.O., Oloruwa, V.O., Ajayi, O., Diagne, A., and Ogunlana, O. (2009). Rice Data Systems in Nigeria: National Rice Survey. 
[15] Opeyemi, G., Adedeji, S. O., Komolafe3*, S. E., Arotiba1, K. and Ifabiyi 3, J. O (2015) Analysis of Consumers' Preference in Patronizing Locally Produced And Imported Rice In Niger State, Nigeria. Nigerian Journal of Agriculture, Food and Environment. 11(3):38-43.

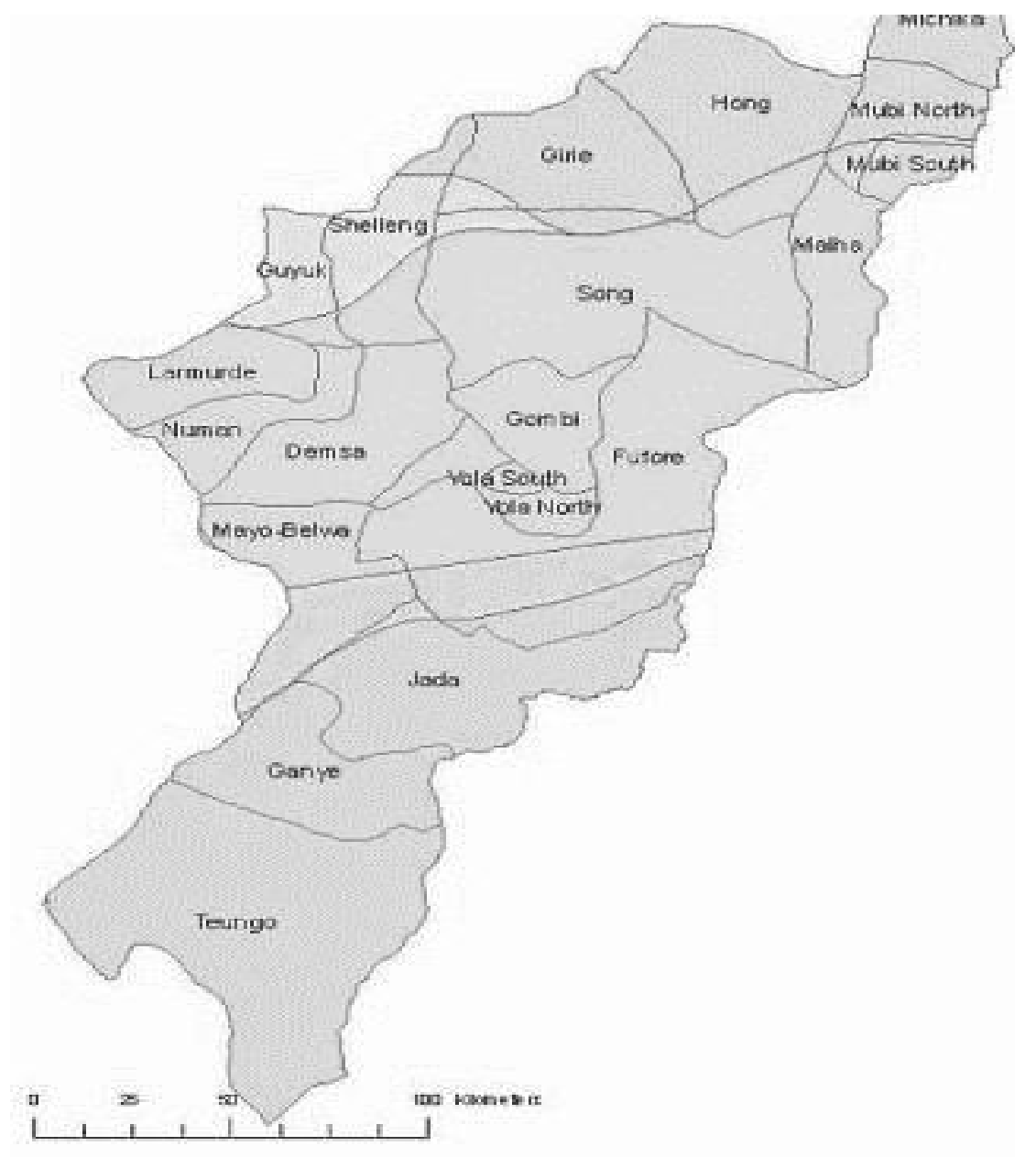

Fig. 1: Map of Adamawa State showing study area

Source: Adebayo and Tukur (1999) 